\title{
Late Holocene forcing of the Asian winter and summer monsoon as evidenced by proxy records from the northern Qinghai-Tibetan Plateau
}

\author{
Xingqi Liu ${ }^{\text {a,* }}$, Hailiang Dong ${ }^{\text {b }}$, Xiangdong Yang ${ }^{a}$, Ulrike Herzschuh ${ }^{c}$, Enlou Zhang ${ }^{a}$, \\ Jan-Berend W. Stuut ${ }^{d}$, Yongbo Wang ${ }^{a}$ \\ a State Key laboratory of Lake Science and Environment, Nanjing Institute of Geography and Limnology, Chinese Academy of Sciences, Nanjing 210008, PR China \\ b Department of Geology, Miami University, Oxford, OH 45056, USA \\ c Alfred Wegener Institute for Polar and Marine Research, Research Unit Potsdam, Telegraphenberg A43, D-14473 Potsdam, Germany \\ d MARUM - Center for Marine Environmental Research, Bremen University, Bremen 28334, Germany
}

\section{A R T I C L E I N F O}

\section{Article history:}

Received 7 July 2008

Received in revised form 20 January 2009

Accepted 28 January 2009

Available online 27 February 2009

Editor: P. DeMenocal

\section{Keywords:}

Late Holocene

Asian Monsoon

solar output

oceanic-atmospheric circulation

Northern Qinghai-Tibetan Plateau

\begin{abstract}
A B S T R A C T
Little is known about decadal- to centennial-scale climate variability and its associated forcing mechanisms on the Qinghai-Tibetan Plateau. A decadal-resolution record of total organic carbon (TOC) and grainsize retrieved from a composite piston core from Kusai Lake, NW China, provides solid evidence for decadal- to centennial-scale Asian monsoon variability for the Northern Qinghai-Tibetan Plateau during the last $3770 \mathrm{yr}$. Intensified winter and summer monsoons are well correlated with respective reductions and increases in solar irradiance. A number of intensified Asian winter monsoon phases are potentially correlated with North Atlantic climatic variations including Bond events 0 to 2 and more recent subtle climate changes from the Medieval Warm Period to the Little Ice Age. Our findings indicate that Asian monsoon changes during the late Holocene are forced by changes in both solar output and oceanic-atmospheric circulation patterns. Our results demonstrate that these forcing mechanisms operate not only in low latitudes but also in mid-latitude regions (the Northern Qinghai-Tibetan Plateau).
\end{abstract}

(c) 2009 Elsevier B.V. All rights reserved.

\section{Introduction}

The Qinghai-Tibetan Plateau has a great effect on the evolution of the Asian monsoon and thus exerts a strong influence on global circulation patterns (Ruddiman and Kutzbach, 1991; An et al., 2001). Many records from lake sediments on the Qinghai-Tibetan Plateau have shown that millennial-scale climatic changes since the late Glacial/Holocene are primarily controlled by the Asian monsoon and are linked with summer insolation (Gasse et al., 1991; Overpeck et al., 1996; Shen et al., 2005; Herzschuh, 2006). Late Pleistocene-Holocene climatic records from Qinghai-Tibetan ice cores have demonstrated a close correlation with the GISP2 ice core records (Thompson et al., 1989). It is assumed that variations in the sun's energy output play a major role in governing past climatic change (Haigh, 1996; Rind, 2002; Versteegh, 2005; Bard and Frank, 2006). Decadal- to centennial-scale variations in monsoonal precipitation, forced by solar activity, and their relation to North Atlantic climate have been described for lowlatitude regions affected by the Asian monsoon (Neff et al., 2001; Gupta et al., 2003; Fleitmann et al., 2003; Wang et al., 2005b; Gupta

\footnotetext{
* Corresponding author. Nanjing Institute of Geography and Limnology, Chinese Academy of Sciences, 73 East Beijing Road, Nanjing 210008, PR China. Tel.: +86 25 86882142(Office); fax: + 862557713063 .

E-mail address: xqliu@niglas.ac.cn (X. Liu).
}

et al., 2005; Selvaraj et al., 2007). However, little information exists about decadal- to centennial-scale variations in Asian monsoonal circulation and the potential mid-latitude influence of the Northern Qinghai-Tibetan Plateau. Here, we present a 3770-year climate record at a decadal resolution inferred from Kusai Lake sediments, Northern Qinghai-Tibetan Plateau, NW China.

\section{Study site}

Kusai Lake $\left(35^{\circ} 37^{\prime}-35^{\circ} 50^{\prime} \mathrm{N}, 93^{\circ} 38^{\prime}-93^{\circ} 15^{\prime} \mathrm{E}, 4475 \mathrm{~m}\right.$ a.s.l.), a saline lake, is situated in the largest almost uninhabited Hoh Xil region of the Northern Qinghai-Tibetan Plateau, NW China (Fig. 1). The lake is fed by the Kusai river at its southwestern margin and has no outflow, resulting in modern salinity levels of $28.54 \mathrm{~g} / 1$. Water depth is between 10 and $50 \mathrm{~m}$ and is deeper in the northwest and shallower in the southeastern part of the lake. The lake area is $254.4 \mathrm{~km}^{2}$ with a catchment area of approximately $3700 \mathrm{~km}^{2}$. The Kusai Lake region is characterized by a strong continental climate indicated by high amplitude fluctuations in annual and daily temperature records (mean annual temperature $\sim 1.5{ }^{\circ} \mathrm{C}$ ). Mean annual precipitation (250 mm) is significantly less than the mean annual evaporation capacity $(1600 \mathrm{~mm})$, resulting in a strong arid climate. The modern vegetation in the Kusai Lake region is desert vegetation dominated by Chenopodiaceae and Artemisia. 


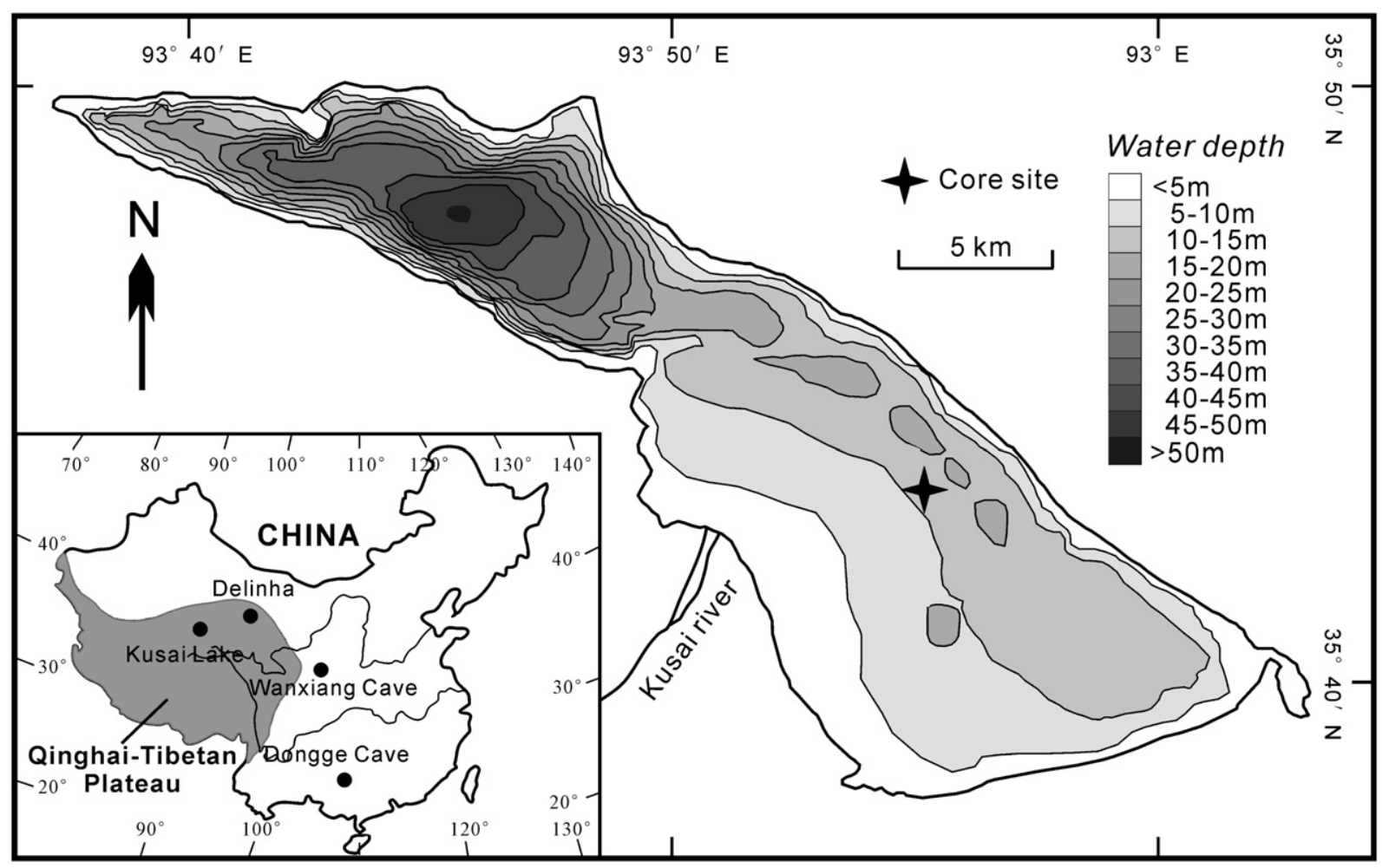

Fig. 1. Location of Kusai Lake and the coring site. Also shown are the locations of Dongge Cave cited in Fig. 5 and Delinha and Wanxiang Cave cited in Fig. 6.

Today, the Asian summer monsoon dominates the region from May to September which brings the greatest amount of moisture to the region. When the summer monsoon retreats at the beginning of September, the winter monsoon occupies the region from midOctober until the beginning of May, bringing dry continental and cold polar air masses to the region (Wang, 2006). An intensified winter monsoon can cause dust storms in Northwestern China between February and April; Hoh Xil experiences the highest frequency of dust storms in Qinghai Province (Fang et al., 1997).

\section{Materials and methods}

During June 2006, we recovered two long sediment cores from the southeastern part of Kusai Lake at a water depth of $14.5 \mathrm{~m}$ using UWITEC coring equipment (Fig. 1). A short core $(17 \mathrm{~cm})$ was also recovered parallel to the long cores, using a gravity corer. The short core was sampled at $0.5 \mathrm{~cm}$ intervals in the field. Additionally, aeolian dust samples deposited in the ice of Kusai Lake were collected in January 2009 as reference materials for grainsize analysis. A composite sediment core was constructed from the two long cores by visual inspection of the stratigraphy in the laboratory. Sediment sub-samples of the composite core were taken at $1 \mathrm{~cm}$ intervals. Alternate subsamples (2-cm spatial intervals) were used for grainsize, total organic carbon (TOC) and total nitrogen (TN) analysis, resulting in a mean temporal resolution of approximately 10-25 calendar years.

Short core slices were radiometrically dated by measuring ${ }^{210} \mathrm{~Pb}$ and ${ }^{137} \mathrm{Cs}$ activity as a function of depth. Sedimentation rates and chronologies were calculated using the ${ }^{210} \mathrm{~Pb}$ data and the constant initial concentration model (CIC), which assumes that sediments have constant initial excess ${ }^{210} \mathrm{~Pb}$ concentrations (Robbins, 1978; Appleby and Oldfield, 1983; Oldfield and Appleby, 1984). ${ }^{137}$ Cs was measured to verify the ${ }^{210} \mathrm{~Pb}$-derived dates.

As pollen concentrations are too low and the sediments contain no terrestrial plant macrofossils, bulk organic carbon was used for accelerator mass spectrometry (AMS) ${ }^{14} \mathrm{C}$ measurements. AMS ${ }^{14} \mathrm{C}$ ages from seven levels in the long composite core were determined from bulk organic carbon at the University of Tokyo Radiocarbon Laboratory, Japan.

Samples were decalcified with $1 \mathrm{~N} \mathrm{HCl}$, rinsed repeatedly with deionized water, and dried. In order to ensure that the measured weight of total organic carbon (TOC) and total nitrogen (TN) in all samples is above the detection limit ( $1 \mu \mathrm{g})$, ca. 5-mg of dried material from each sample was weighed and analyzed using a CE Model 440 Elemental Analyzer using acetanilide as a standard. Analytical precision based on repeated measurements of the sample and the standard was calculated to be $5 \%$ for both total carbon (TOC) and total nitrogen (TN). The pretreated samples for TOC and TN measurements were also used for organic carbon isotope determinations $\left(\delta^{13} \mathrm{C}_{\mathrm{org}}\right)$. The $\delta^{13} \mathrm{C}$ value of $\mathrm{CO}_{2}$ generated by combusting and oxidizing dried samples, was measured in a Finnigan Delta-plus Mass Spectrometer. All isotopic values are reported in standard $\delta$-notation in per mil (\%) relative to V-PDB.

For grainsize determinations, samples were pretreated with 10$20 \mathrm{ml}$ of $30 \% \mathrm{H}_{2} \mathrm{O}_{2}$ to remove organic matter, washed with $10 \% \mathrm{HCl}$ to remove carbonates, rinsed with deionized water, and then treated with $10 \mathrm{ml}$ of $0.05 \mathrm{M}\left(\mathrm{NaPO}_{3}\right)_{6}$ on an ultrasonic vibrator for $10 \mathrm{~min}$ to facilitate dispersion. Grainsize distributions between $0.02 \mu \mathrm{m}$ and $2000 \mu \mathrm{m}$ were determined using a Malvern Mastersizer 2000 analyzer. The end-member-modeling algorithm (EMMA) of Weltje (1997), which can convert measured grain-size distributions into proportional contributions of an optimal set of end members (Weltje and Prins, 2003, 2007), was used to calculate the end members from the total set of grainsize measurements $(N=301)$ of the Kusai Lake composite long core.

\section{Results}

\subsection{Chronology}

The chronology of the $606 \mathrm{~cm}$ composite sediment core from Kusai Lake is based on ${ }^{210} \mathrm{~Pb} /{ }^{137} \mathrm{Cs}$-dating and 7 accelerator mass spectrometry (AMS) ${ }^{14} \mathrm{C}$ ages determined on bulk organic carbon (Table 1; Fig. 2 ). 
Table 1

${ }^{14} \mathrm{C}$ AMS ages analyzed on TOC and calibrated ages for Kusai Lake.

\begin{tabular}{|c|c|c|c|c|c|c|}
\hline $\begin{array}{l}\text { Sample } \\
\text { number }\end{array}$ & Lab I.D. & $\begin{array}{l}\text { Depth } \\
(\mathrm{cm})\end{array}$ & $\begin{array}{l}{ }^{14} \mathrm{C} \text { age } / \mathrm{yr} \\
\mathrm{BP}(1 \sigma)\end{array}$ & $\delta^{13} \mathrm{C} \%$ & $\begin{array}{l}\text { Reservoir- } \\
\text { corrected }{ }^{14} \mathrm{C} \\
\text { age by } 3400 \mathrm{yr}\end{array}$ & $\begin{array}{l}\text { Calendar } \\
\text { age/cal yr } \\
\mathrm{BP}(2 \sigma)\end{array}$ \\
\hline ks1-1 82 & TKa-14104 & $82-83$ & $3670 \pm 35$ & -18.9 & $270 \pm 35$ & $\begin{array}{l}281-335 \\
(308)\end{array}$ \\
\hline ks1-1 102 & TKa-14105 & $102-103$ & $3855 \pm 30$ & -23.9 & $455 \pm 30$ & $\begin{array}{l}478-536 \\
(530)\end{array}$ \\
\hline ks1-2 26 & TKa-14107 & $184-185$ & $4580 \pm 35$ & -25.0 & $1180 \pm 35$ & $\begin{array}{l}1047-1180 \\
(1100)\end{array}$ \\
\hline ks1-2 126 & TКа-14109 & $284-485$ & $5235 \pm 35$ & -24.1 & $1835 \pm 35$ & $\begin{array}{l}1698-1868 \\
(1850)\end{array}$ \\
\hline ks1-3d 66 & TKa-14234 & $470-471$ & $6257 \pm 45$ & -21.9 & $2875 \pm 35$ & $\begin{array}{l}2871-3084 \\
(2900)\end{array}$ \\
\hline ks1-4 70 & ТКа-14112 & $573-574$ & $6630 \pm 40$ & -24.1 & $3230 \pm 40$ & $\begin{array}{l}3377-3557 \\
(3550)\end{array}$ \\
\hline ks1-4 100 & ТКа-14113 & $603-604$ & $6955 \pm 40$ & -23.2 & $3555 \pm 40$ & $\begin{array}{l}3718-3930 \\
(3750)\end{array}$ \\
\hline
\end{tabular}

${ }^{210} \mathrm{~Pb} /{ }^{137} \mathrm{Cs}$-dating detected significant levels of unsupported ${ }^{210} \mathrm{~Pb}$ in the top $17 \mathrm{~cm}$ of the short core. The oldest ${ }^{210} \mathrm{~Pb}$-datable sediments in the core are situated at a depth of $16.5 \mathrm{~cm}$ which corresponds to an age of 1922 A.D. based on the CIC model (Fig. 2A; Robbins, 1978; Appleby and Oldfield, 1983; Oldfield and Appleby, 1984). The initial rise in ${ }^{137} \mathrm{Cs}$ activity occurs at $10.25 \mathrm{~cm}$ and can probably be ascribed to the onset of significant fallout in 1954 A.D. in the Northern Hemisphere. A single maximum ${ }^{137} \mathrm{Cs}$ value at $5.75 \mathrm{~cm}$ corresponds to 1976 A.D. (Fig. 2A) when China's largest atmospheric nuclear test was conducted (Norris et al., 1994). Therefore, the ${ }^{210} \mathrm{~Pb}$-based chronology is generally in good agreement with the ${ }^{137}$ Cs-based chronology (Fig. 2A).
The age $\left({ }^{14} \mathrm{C}\right) /$ depth correlation for the Kusai Lake record is shown in Fig. 2B. A comparison of the ${ }^{210} \mathrm{~Pb}$ - and ${ }^{137} \mathrm{Cs}$-based ages at a depth of $11 \mathrm{~cm}$ (1950 A.D. or $0 \mathrm{yr} \mathrm{BP}$ ) with the age at the same level determined from interpolation between the seven AMS ${ }^{14} \mathrm{C}$ dates (i.e., $3400 \mathrm{yr} \mathrm{BP}$ ) suggests that the radiocarbon age is in excess of the ${ }^{210} \mathrm{~Pb}$ and ${ }^{137} \mathrm{Cs}$ age by $3400 \mathrm{yr}$ (Fig. 2B). There are two possible reasons which could account for this discrepancy. One is that discontinuous deposition may have occurred at the top part of the core (Jin et al., 2005; Morrill et al., 2006). However, no evidence, such as unconformities or changes in sediment texture, was found in the top $82 \mathrm{~cm}$. Additionally, XRD analysis on the whole core shows that authigenic minerals are mainly dominated by aragonite and that no other evaporitic minerals such as gypsum or halite are present. Another possible explanation is that the ages obtained from measurements on bulk organic carbon are affected by a reservoir effect, which is common in the radiocarbon dating of lacustine sediments in the aridsemiarid regions of Western China and is especially true for saline lakes on the Qinghai-Tibetan Plateau. These lakes have different reservoir effects varying from several hundred to thousands of years (Fontes et al., 1996; Shen et al., 2005; Herzschuh et al., 2006; Morrill et al., 2006; Liu et al., 2008). The Kusai Lake sediments generally have low $\mathrm{C} / \mathrm{N}$ ratios $(<10$, Fig. 3 ), indicating that organic matter largely originates from lacustrine algae. We therefore suggest that, in Kusai Lake, there is a ${ }^{14} \mathrm{C}$ reservoir effect similar to other saline lakes on the Qinghai-Tibetan Plateau (Fontes et al., 1996; Shen et al., 2005; Herzschuh et al., 2006; Morrill et al., 2006; Liu et al., 2008). It is quite likely that the ${ }^{14} \mathrm{C}$ reservoir effect has changed over time. However, the apparent ages lie in a steady sequence between 82 and $606 \mathrm{~cm}$, suggesting stable hydrochemical conditions in the lake and that the ${ }^{14} \mathrm{C}$ reservoir effect would have been constant through time. Thus, we then assumed a constant ${ }^{14} \mathrm{C}$ reservoir effect over the time scale of the long composite core and subtracted a value of 3400 from all ${ }^{14} \mathrm{C}$ ages

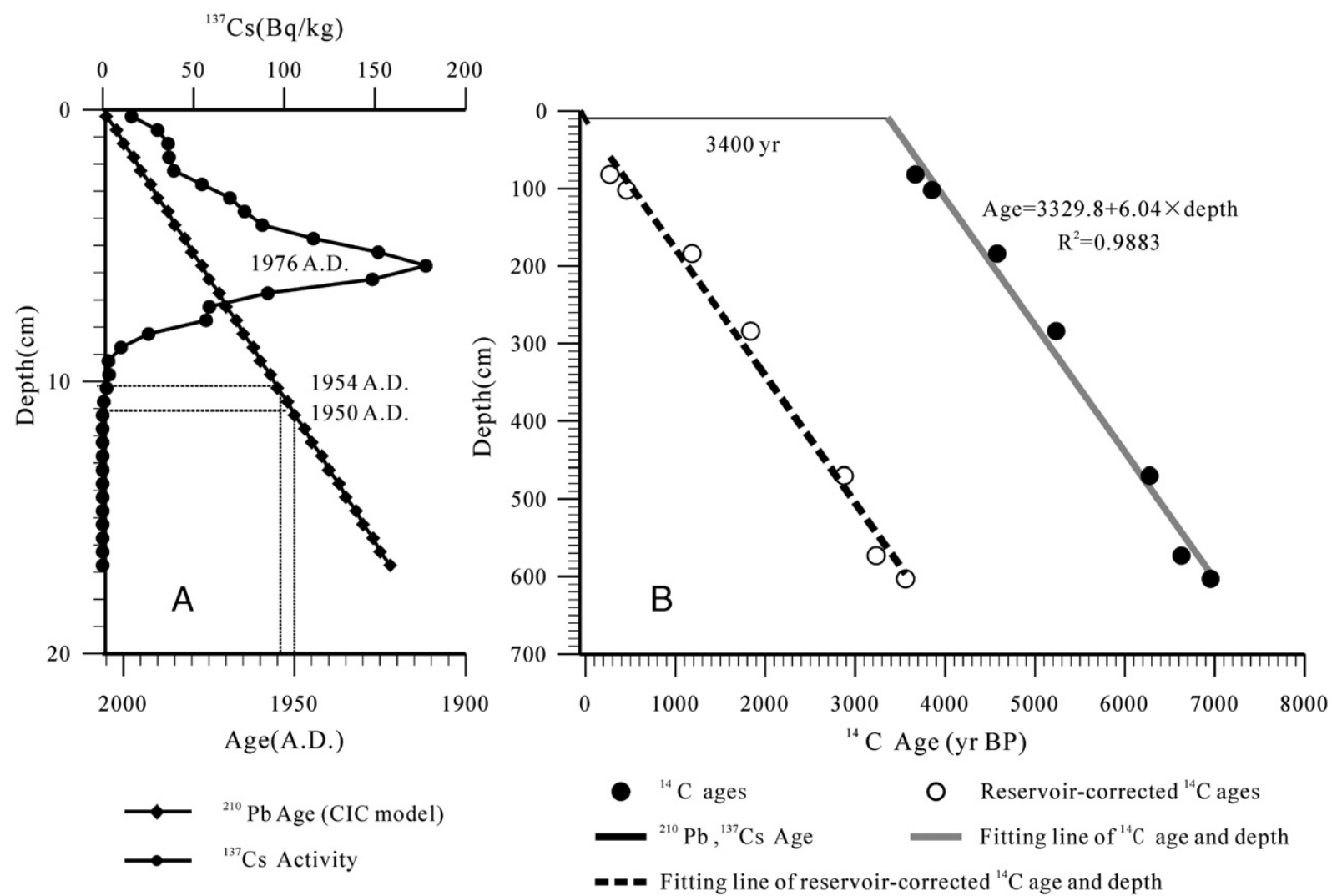

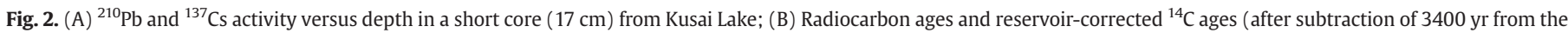

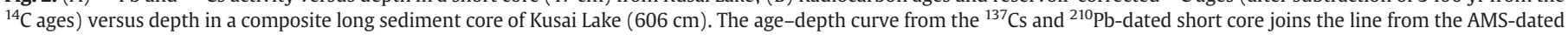
core when the ${ }^{14} \mathrm{C}$ dates are adjusted by $3400 \mathrm{yr}$. 

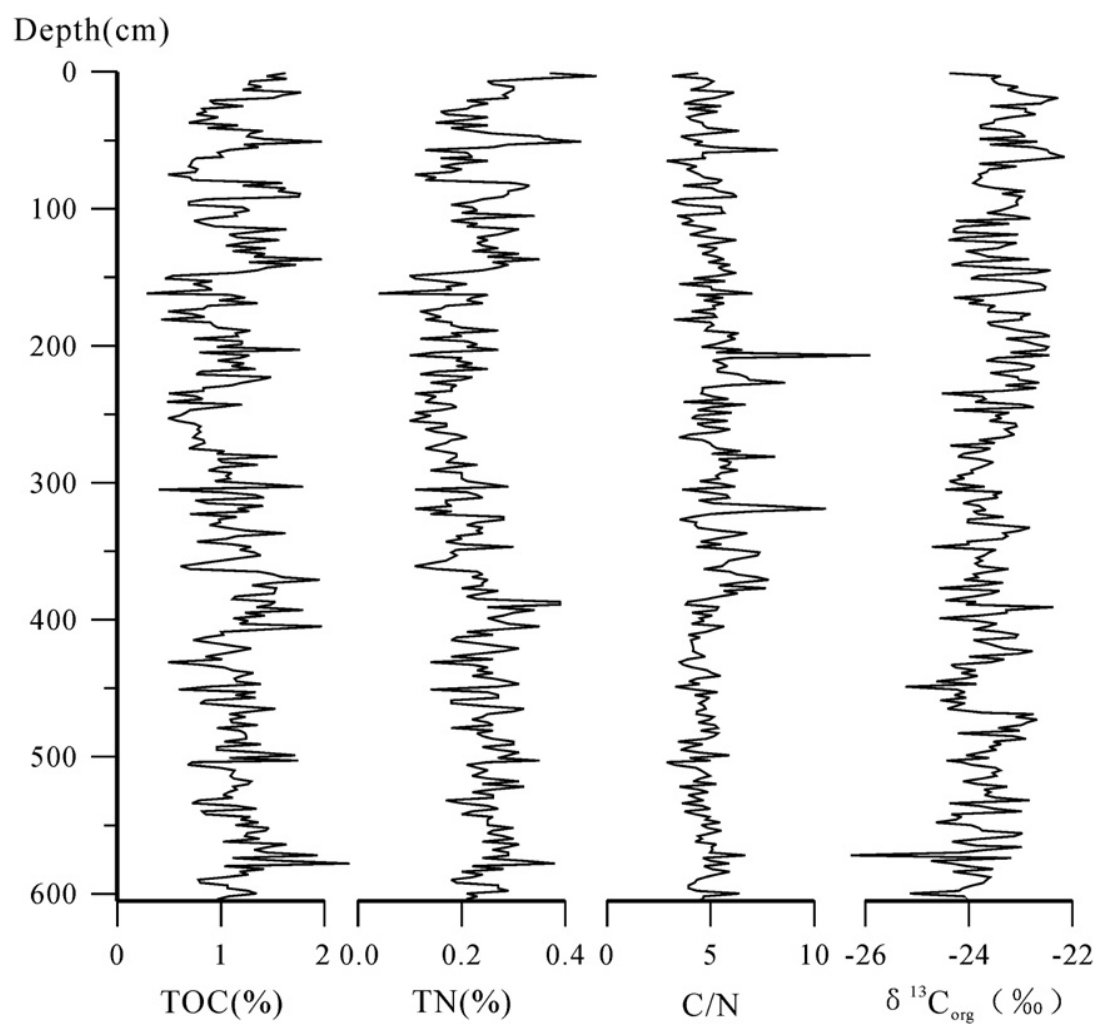

Fig. 3. TOC, TN, C/N and $\delta^{13} \mathrm{C}_{\text {org }}$ variations versus depth for the composite core of Kusai Lake.

prior to calibration. All reservoir-corrected ${ }^{14} \mathrm{C}$ ages are converted to calendar year ages using the Calib 5.1 program (Table 1 ) (Reimer et al., 2004). The age of each sampling interval was established by extrapolation or linear interpolation between two adjacent calendar year ages. Sedimentation in the core spans from approximately $3770 \mathrm{yr}$ before present (defined as 1950 A.D.) until 2006 (when the core was collected), with a nearly constant sedimentation rate of $0.20 \mathrm{~cm} / \mathrm{yr}$.

\subsection{TOC, TN, $C / N$ and $\delta^{13} C_{\text {org }}$}

Sedimentary organic matter in a lake generally originates from autochthonous and allochthonous sources, which can be distinguished by $\mathrm{C} / \mathrm{N}$ ratios of lacustrine organic matter. Lacustrine algae have $\mathrm{C} / \mathrm{N}$ ratios $<10$, submerged and floating aquatic macrophytes or organic matter of a mixed source have $\mathrm{C} / \mathrm{N}$ ratios between 10 and 20, whereas emerged and terrestrial plants have $\mathrm{C} / \mathrm{N}$ ratios $>20$ (Stuiver,
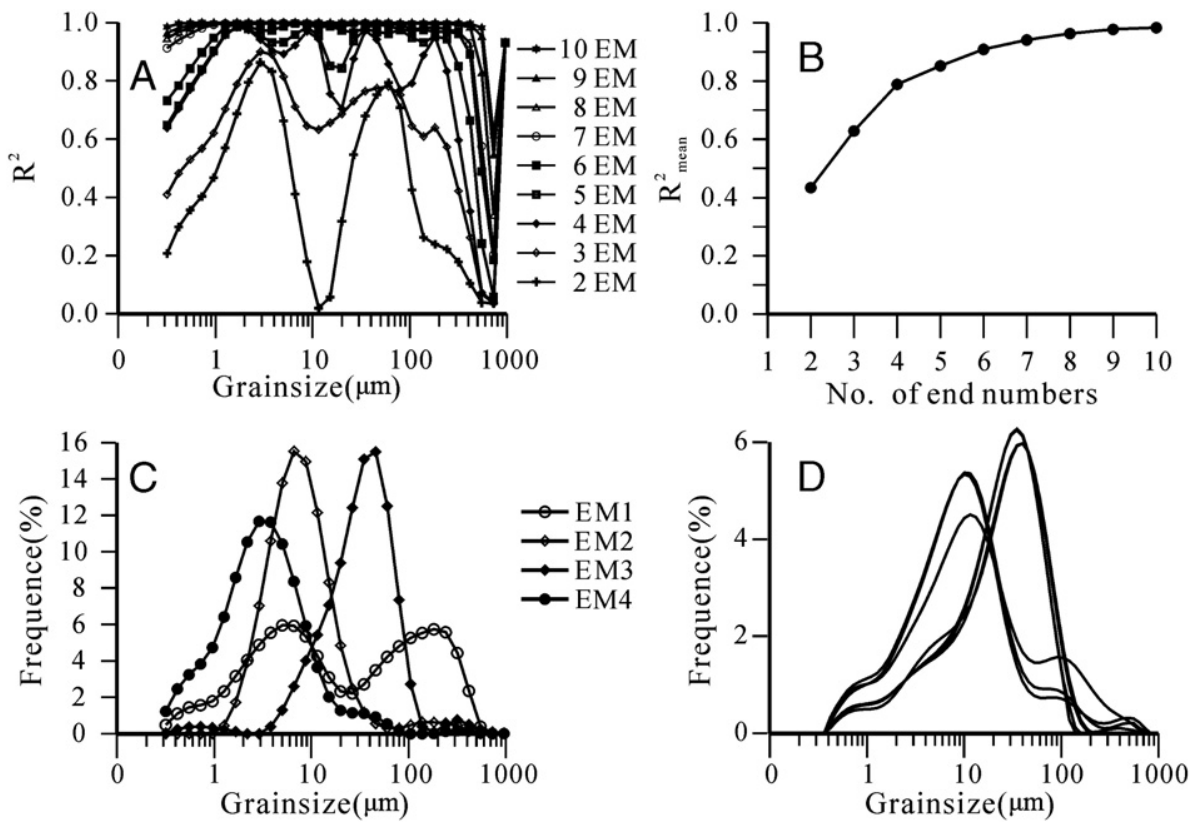

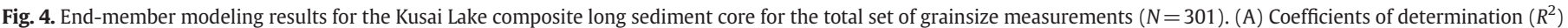

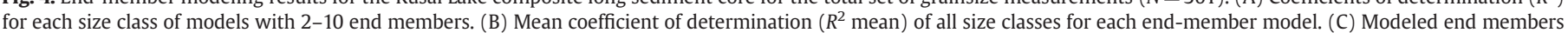
calculated from the total set of grainsize measurements of the Kusai Lake sediment core. (D) Grainsize distributions of aeolian samples collected in Kusai Lake area. 
1975; Krishnamurthy et al., 1986; Meyers, 2001). The carbon isotopic composition of organic matter in lake sediments can also be used to assess organic matter source. $C_{4}$ land plants have an average $\delta^{13} \mathrm{C}$ value of $-14 \%$, whilst $C_{3}$ land plants and lacustrine algae have an average $\delta^{13} \mathrm{C}$ value of $-28 \%$ (Smith and Epstein, 1971; O'Leary, 1988).

TOC and TN results exhibit broadly similar changes and vary between 0.28 and $2.78 \%$ (range of $2.50 \%$ ) and between 0.10 and $0.46 \%$ (range of $0.36 \%$ ) respectively. $\mathrm{C} / \mathrm{N}$ ratios are largely less than 10 . The $\delta^{13} \mathrm{C}$ values of organic matter $\left(\delta^{13} C_{o r g}\right)$ range from $-26.3 \%$ o to $-22.2 \%$ with an average of $-23.6 \%$ (Fig. 3 ). The measured $\mathrm{C} / \mathrm{N}$ ratios and stable carbon isotopes of organic matter in the Kusai lake sediments indicate that organic matter originates mainly from lacustrine algae and that TOC content reflects the primary productivity of the lake (Hollander and McKenzie, 1991; Hodell and Schelske, 1998; Meyers, 2001).

\subsection{Grainsize}

The frequency curve of grainsize distribution produced in one sedimentary or transportation process is usually unimodal, whilst the involvement more than one sedimentary or transportation process in sediment formation may yield a polymodal distribution. Sediments with a polymodal distribution have been mathematically proven to be the sum of all sedimentary components, of which different transportdeposition processes can be recognized based on EMMA analysis (Weltje, 1997; Weltje and Prins, 2003, 2007). The minimum number of end members (EMs) required for a satisfactory approximation of the data is determined by the coefficient of determination $\left(R^{2}\right)$ for each size-class (Fig. 4A) and the mean coefficient of determination $\left(R_{\text {mean }}^{2}\right.$ ) (Fig. 4B) that can be reproduced by the grainsize distribution of the approximated end members. A four-end-member model which explains $79 \%$ of the variance is needed to describe the variation in the total set of grainsize distributions in the Kusai Lake sediment core (Fig. 4B). The down core average proportional contributions of four end members are 8.5\% (EM1), 13.6\% (EM2), 22.3\% (EM3), and 55.5\% (EM4). The three end members, EM4, EM2, and EM3, have dominant modal grainsizes of $2.9 \mu \mathrm{m}$ (EM4), $6.6 \mu \mathrm{m}$ (EM2), and $45.8 \mu \mathrm{m}$ (EM3) (Fig. 4C), respectively, while the EM1 end member has a bimodal distribution with modal grainsizes of $5.0 \mu \mathrm{m}$ and $182 \mu \mathrm{m}$. Aeolian dust sam0070les collected in the Kusai Lake area have dominant modal grainsizes of ca.10 $\mu \mathrm{m}$ or ca.40 $\mu \mathrm{m}$ (Fig. 4D). The grainsize distributions of EM2 and EM3 are similar to those of aeolian samples collected in winter in Kusai Lake area. Hence, EM2 and EM3 are

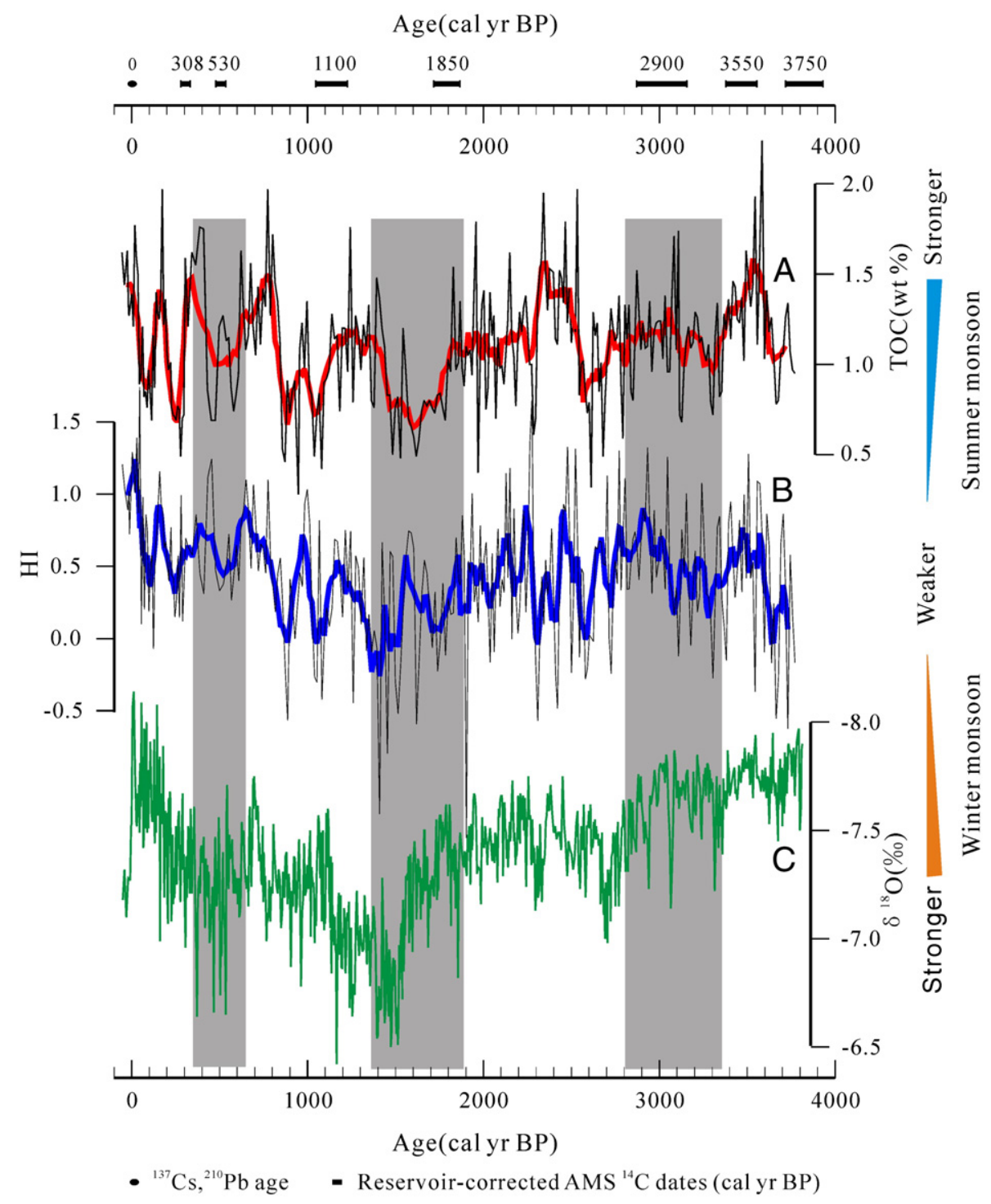

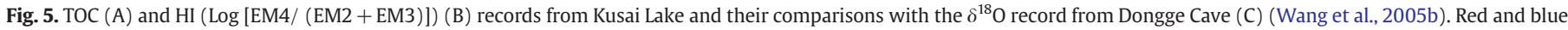

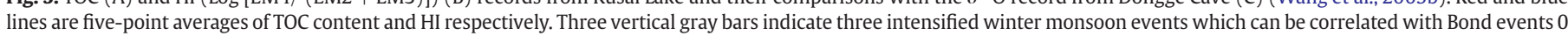
to 2. (For interpretation of the references to colour in this figure legend, the reader is referred to the web version of this article.) 
interpreted as fine-grained distal and coarse-grained proximal aeolian transported dust, respectively. In arid regions, rivers with low discharge are normally insufficient to transport coarse particles to the central part of a lake (Deckker et al., 1991; Xiao et al., 2007).Thus we interpret the fine-grained material of EM4 as non-aeolian mud associated with fluvial transport. The bimodally-distributed EM1 is possibly an example of glacially-supplied material (Weltje and Prins, 2007), although independent evidence for this is lacking. As the mean proportional contribution of EM1 is just $8.5 \%$ of the total sediments, we exclude EM1 from further analysis and use Log [EM4/ (EM2 + EM3)] as a humidity index (HI).

\section{Discussion}

\subsection{The late Holocene Asian Monsoon variations}

As organic matter in Kusai Lake originates mainly from lacustrine algae and minerogenic sediments are likely transported by both aeolian and fluvial processes, we can use these proxies to describe changes in the sedimentary environment related to variations in hydrologic energy and dust activity. When the winter monsoon intensifies, low precipitation and cold temperatures lead to low primary productivity in the lake, and a high proportion of aeolian dust input relative to the input of fluvial material. We therefore use low TOC content and low HI (Log [EM4/ (EM2 + EM3)] to infer strong winter monsoon activity (Fig. 5). Conversely, when the summer monsoon prevails, high precipitation and warm temperatures lead to high primary productivity in the lake, and a low proportion of aeolian dust input relative to that of fluvial material transported into the lake. Thus, we suggest that high TOC content and high HI (Log [EM4/ (EM2 + EM3)] can be used to indicate strong summer monsoonal conditions (Fig. 5).

A slight decrease in TOC content and HI reveals a gradual weakening in the Asian summer monsoon between 3700 cal yr BP and 1500 cal yr BP (Fig. 5). This weakening, which is widely indicated by lake level regression across China (Jin et al., 2005; Morrill et al., 2006; Herzschuh, 2006; Selvaraj et al., 2007), is generally interpreted as a response to decreasing summer insolation (Overpeck et al., 1996; Gupta et al., 2003).

Beginning at 1500 cal yr BP, a gradual increase in TOC content and $\mathrm{HI}$, with large and frequent fluctuations, probably is suggestive of an intensification in monsoonal circulation since 1500 cal yr BP (Fig. 5). This is also visible in the Dongge cave (Wang et al., 2005b) and Oman Margin records (Gupta et al., 2003). The climate climatic fluctuation, exhibited particularly well by TOC content, is well correlated with the most recent subtle climate changes from the Medieval Warm Period to the Little Ice Age in the North Atlantic region (Figs. 6 and 7B; also see detailed discussion later).

The Kusai Lake records of winter and summer monsoon strength during the late Holocene inferred from a five-point running average of TOC content and HI (within the dating errors) show good correlation with the radiometrically dated $\delta^{18} \mathrm{O}$ records from stalagmites at Dongge Cave on a multicentennial-scale (Wang et al., 2005b; Fig. 5). Strong winter and summer monsoon phases recorded in Kusai Lake correlate well with higher and lower $\delta^{18} \mathrm{O}$ values from Dongge Cave (Wang et al., 2005b) respectively, implying that there is an inverse correlation between the strengths of the winter and summer monsoons on the Northern Qinghai-Tibetan Plateau. Moreover, the Kusai Lake records of multicentennial-scale changes in winter and summer monsoon show a better correlation with an 1810-year record of Asian Monsoon change from Wanxiang Cave (Zhang et al., 2008) and with a 1437-year reconstruction of precipitation from tree rings in Delingha on the NE Qinghai-Tibetan Plateau (Shao et al., 2005; Fig 6).

During the late Holocene, there are three weak Asian monsoon events indicated by low TOC content and low HI (three vertical grey bars shown in Fig. 5) on the Northern Qinghai-Tibetan Plateau.
Furthermore, three weak Asian monsoon events of relatively low TOC content around A.D.1450-1550, 1650-1750, and 1800-1900 can be correlated to low precipitation levels recorded in tree rings in the NE Qinghai-Tibetan Plateau (Fig. 6). These weak Asian monsoon events (within dating errors) show a possible correlation to the Holocene icerafting events in the North Atlantic (i.e. Bond events 0 to 2) (Bond et al., 2001) and the Little Ice Age (LIA) (Keigwin, 1996) respectively. The suggestion of such a link between the Asian southwest monsoon and the North Atlantic climate was first outlined by Gupta et al. (2003, 2005). This suggests that late Holocene climatic events in the North Atlantic had counterpart events in the Asian monsoonal system on the Northern Qinghai-Tibetan Plateau.

Previous studies demonstrate a link between solar activity and Asian monsoon intensity (Fleitmann et al., 2003; Wang et al., 2005b; Selvaraj et al., 2007; Zhang et al., 2008). In order to test such a link on the Northern Qinghai-Tibetan Plateau, we compared the detrended TOC ( $\triangle \mathrm{TOC}$ ) record from Kusai Lake to residual atmospheric ${ }^{14} \mathrm{C}$ from tree ring records (Stuiver et al., 1998), a proxy for solar activity (Fig. 7A). We found that the variations in Asian monsoon intensity indicated by $\triangle \mathrm{TOC}$ are generally in good agreement with $\Delta^{14} \mathrm{C}$ fluctuations on decadal- to centennial-scales. Intensified Asian winter monsoon activity (lower $\triangle \mathrm{TOC}$ ) corresponds to lower solar irradiance (larger $\Delta^{14} \mathrm{C}$ ) when the sun is active, while strong Asian summer monsoons (higher $\triangle \mathrm{TOC}$ ) correspond to higher solar irradiance ( maller $\Delta^{14} \mathrm{C}$ ) when the sun is quiet, implying a possible link between solar activity and Asian monsoon intensity on the Qinghai-Tibetan Plateau. To further assess this linkage, we provide a detailed comparison of climate change in Kusai Lake with records of solar irradiance from cosmogenic nuclides over the past millennium (Fig. 7B) (Bard et al., 2000). A decrease in TOC content suggests a period of increased Asian winter monsoon activity between 1000 and

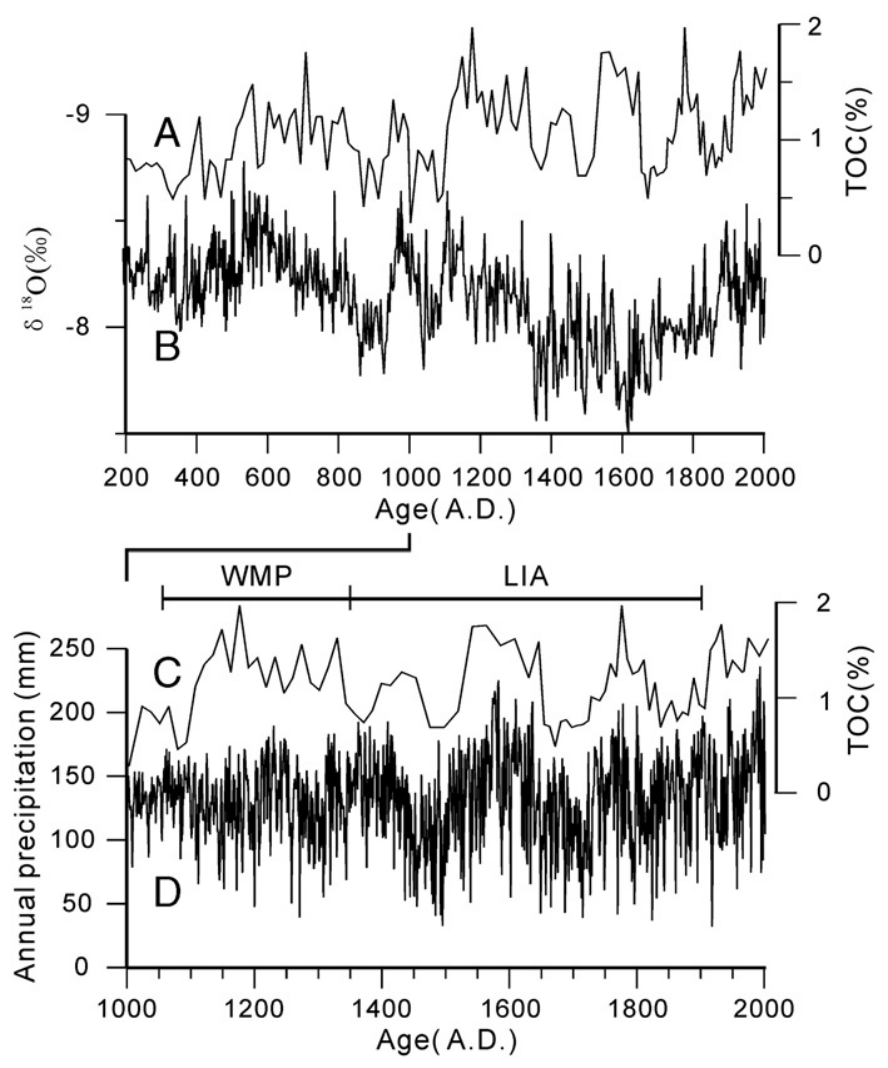

Fig. 6. TOC records from the Kusai Lake composite long sediment core (A, C) and the comparisons with the 1810 -year $\delta^{18} \mathrm{O}$ record from Wanxiang Cave (B) (Zhang et al., 2008 ) and the 1437-year precipitation reconstruction from tree rings in Delingha on the NE Qinghai-Tibetan Plateau (D) (Shao et al., 2005). LIA and MWP refer to Little Ice Age and Middle Warm Period respectively. 


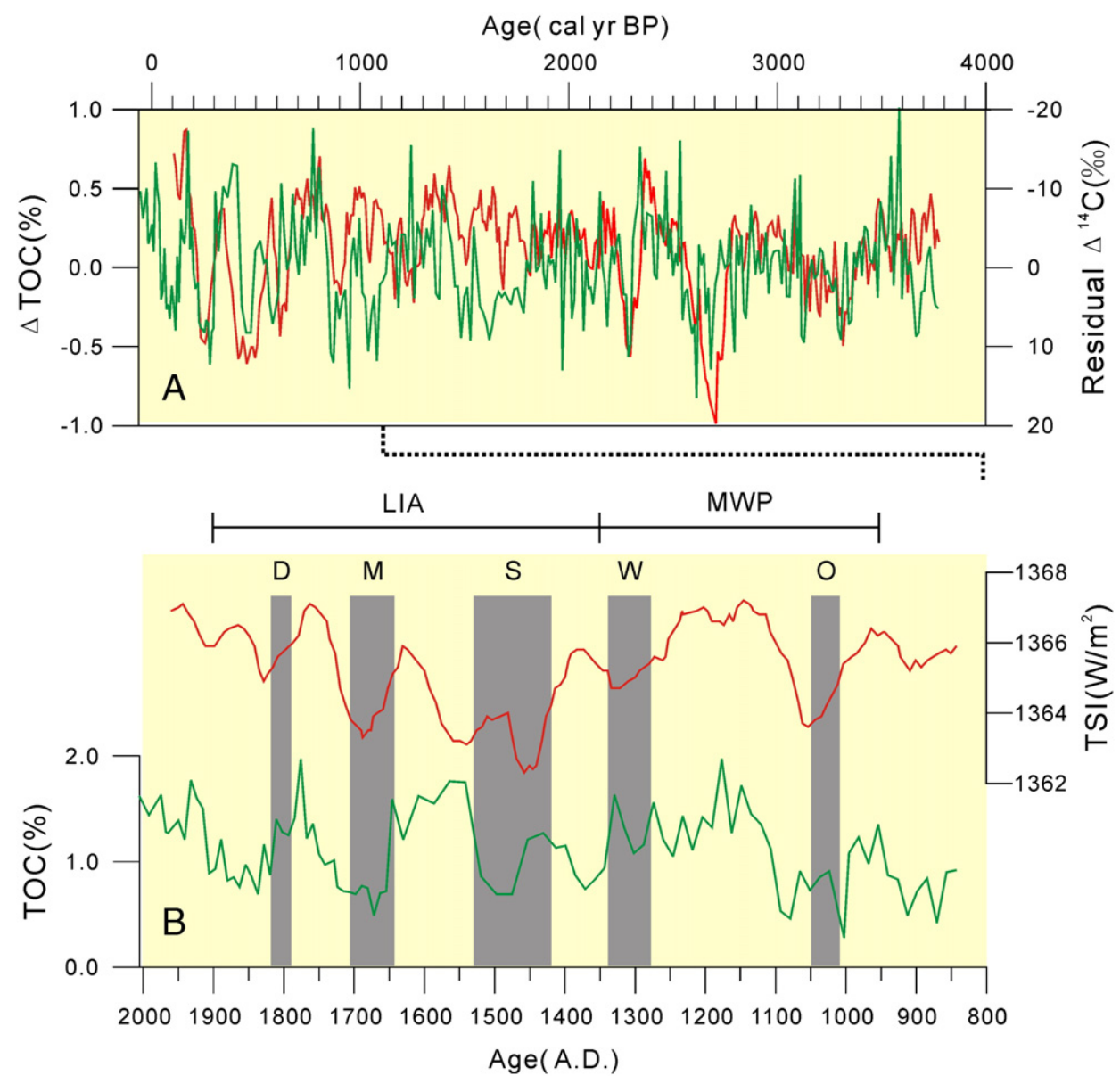

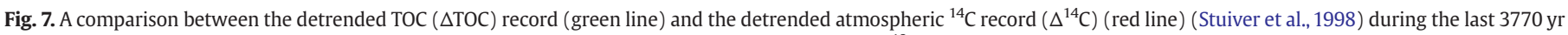

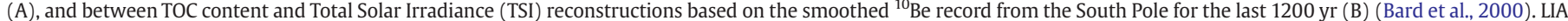

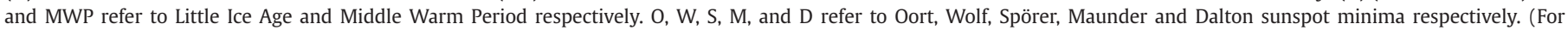
interpretation of the references to colour in this figure legend, the reader is referred to the web version of this article.)

1100 A.D., coincident with the Oort Minimum centered around $1050 \mathrm{~A}$. D.. After this time, TOC content increases significantly between 1100 and 1275 A.D., possibly implying an intensification in the Asian summer monsoon during this time which correlates well with the Medieval Warm Period. From 1275 A.D. Onwards, fluctuations in climate become more frequent. Four distinct periods of stronger Asian winter monsoon, indicated by low TOC content, occurred at A.D. 1325$1390,1450-1550,1650-1750$ and $1800-1900$. These four periods correlate well with four different sunspot minima i.e., Wolf, Spörer, Maunder and Dalton Minimum (Fig. 7B). The culmination of the LIA which corresponds to the Maunder Minimum is indicated by the lowest TOC content between 1650 and 1750 A.D.

Using the program REDFIT (Schulz and Mudelsse, 2002), spectral analysis of the detrended TOC content in Kusai Lake over the last $3770 \mathrm{yr}$ reveals statistically significant centennial periodicities centered on 611, 204, 153 yr above the 90\% confidence level (Fig. 8). These periodicities are very similar to significant periods in the $\delta^{18} \mathrm{O}$ record from Dongge Cave (558, 206, and 159 yr) (Wang et al., 2005b) and $\Delta^{14} \mathrm{C}$ record $(512,206$, and $148 \mathrm{yr}$ ) (Stuiver and Braziunas, 1993) which indicates that centennial monsoonal variations are similar throughout eastern Asia.

\subsection{Forcing mechanisms}

Monsoonal circulation results from seasonal changes in land-sea atmospheric pressure distribution (Li and Yanai, 1996) which is triggered by variations in insolation due to orbital changes and solar output over decadal to millennial time scales (Wang et al., 2005a). The thermal difference between the Asian landmass and the adjacent oceans is enhanced by the thermal and dynamic effect of the QinghaiTibetan Plateau (An et al., 2001). During periods of strong summer monsoon circulation, the land-sea-contrast is furthermore strengthened by increased latent heat release over the continent as a result of heavy monsoonal rains in southern and eastern Asia (including the eastern Tibetan Plateau, Ueda et al., 2003) which intensifies the low pressure cell over the continent (Webster, 1987).

Relatively small long-term solar variations could influence temperatures over the Northern Hemisphere continents and hence, the land-sea contrast is weak during periods of weak solar output. Numerical simulations based on reduced solar output during the Maunder Minimum indicate that the monsoon could be sensitive to changes of only $0.25 \%$ in solar output (Shindell et al., 2001). Our data show that intensified Asian summer (winter) monsoon on the Northern QinghaiTibetan Plateau during the late Holocene are well correlated with increased (reduced) solar output, and there are some common periodicities in both the Asian monsoon and $\Delta^{14} \mathrm{C}$ records. These correlations suggest that the intensity of the Asian monsoon on the Northern Qinghai-Tibetan Plateau could be directly related to changes in solar activity. Additionally, GCM modeling indicates that the atmospheric response to reduced solar irradiance could lead to the coincident increases in North Atlantic ice rafting and cooling of both the ocean surface and atmosphere near Greenland (Rind and Overpeck, 1993) which could indirectly lead to a reduction in Asian summer monsoon intensity, as has been suggested by many well-dated low-latitude records (Neff et al., 2001; Fleitmann et al., 2003; Wang et al., 2005b; Selvaraj et al., 2007). Mid-northern-latitude climatic events have been 


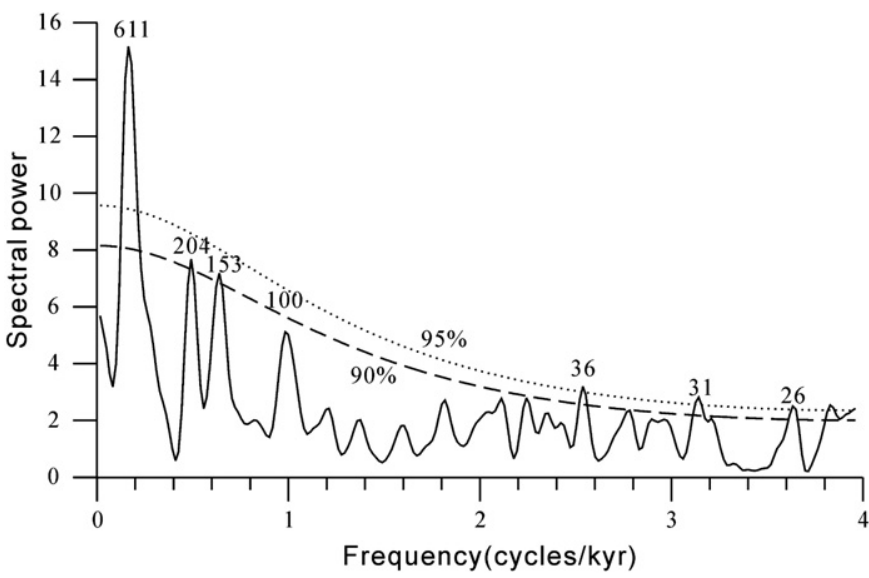

Fig. 8. Results of spectral analysis for the detrended TOC record from Kusai Lake over the last 3770 yr. Peaks are labeled with their period in years above 90\% (dashed line) confidence level. Dotted line shows 95\% confidence levels.

recorded in Kusai Lake on the Qinghai-Tibetan Plateau and seem (within dating error) to have occurred simultaneously to smallamplitude changes in the North Atlantic region such as Bond Events $0-2$ and the Little Ice Age. These correlations support the hypothesis that the production of North Atlantic Deep Water potentially provides an indirect mechanism for the amplification and global transmission of solar signals (Bond et al., 2001). In summary, our findings indicate that both changes in oceanic-atmospheric circulation and in solar output result in changes in the Asian monsoonal system during the late Holocene, not only at low latitudes but also in the mid-latitude region of the Northern Qinghai-Tibetan Plateau.

\section{Conclusions}

High-resolution TOC content and grainsize records from Kusai Lake on the northern Qinghai-Tibetan Plateau covering the last $3770 \mathrm{yr}$ show that there is a close relationship between late Holocene Asian monsoon variability on the Northern Qinghai-Tibetan Plateau and the atmospheric ${ }^{14} \mathrm{C}$ record (a proxy for solar output), i.e., intensified winter and summer monsoonal activity is correlated with respective reductions and increases in solar irradiance. This suggests that solar activity might modulate both Asian winter and summer monsoons. Additionally, three distinct phases of intensified Asian winter monsoon activity can be correlated with Holocene ice-rafting events in the North Atlantic (i.e. Bond events 0 to 2). More recent subtle climatic changes from the Medieval Warm Period to the Little Ice Age in the North Atlantic region are also documented by variations in the Asian winter and summer monsoons on the Northern Qinghai-Tibetan Plateau. Our data indicate that Asian monsoon changes in mid-latitudes (the Northern Qinghai-Tibetan Plateau) during the late Holocene, result from changes in both solar output and oceanic-atmospheric circulation patterns. Our findings show that Kusai Lake could be a key site for future study to better understand the decadal to centennial Asian monsoon variations on the Qinghai-Tibetan Plateau and their effect on global climatic changes over longer geological time scales.

\section{Acknowledgements}

We thank Bo Yang, Rong Wang for their help with fieldwork. We thank Gert Jan Weltje for providing the end-memeber modeling algorithm (EMMA). We are grateful to two anonymous reviewers and associate editor Peter deMenocal for their valuable comments which significantly improved the quality of the manuscript. This work was supported by the National Basic Research Program of China (Grant Nos. 2005CB422002, and 2004CB720200) and the National Natural Science Foundation of China (Grant No. 40772108).

\section{References}

An, Z.S., Kutzbach, J.E., Prell, W.L., Porter, S.C., 2001. Evolution of Asian monsoons and phased uplift of the Himalaya-Tibetan plateau since Late Miocene times. Nature $411,62-66$.

Appleby, P.G., Oldfield, F., 1983. The assessment of ${ }^{210} \mathrm{~Pb}$ data from sites with varying sediment accumulation rates. Hydrobiology 103, 29-35.

Bard, E., Frank, M., 2006. Climate change and solar variability: what's new under the sun? Earth Planet. Sci. Lett. 248, 1-14.

Bard, E., Raisbeck, G.M., Yiou, F., Jouzel, J., 2000. Solar irradiance during the last 1,200 yr based on cosmogenic nuclides. Tellus, Ser. B 52, 985-992.

Bond, G., Kromer, B., Beer, J., Muscheler, R., Evans, M., Showers, W., Hoffmann, S., LottiBond, R., Hajdas, I., Bonani, G., 2001. Persistent solar influence on North Atlantic climate during the Holocene. Science 294, 2130-2136.

Deckker, P.D., Correge, T., Head, J., 1991. Late Pleistocene record of cyclic eolian activity from tropical Australia suggesting the Younger Drays is not an unusual climatic event. Geology 19, 602-605.

Fang, Z.Y., Zhu, F.K., Jiang, J.X., Qian, Z.A., 1997. Research of Dust-storm in China. Meteorological Press, Beijing. (in Chinese).

Fleitmann, D., Burns, S.J., Mudelsee, M., Neff, U., Kramers, J., Mangini, A., Matter, A., 2003. Holocene forcing of the Indian Monsoon recorded in a stalagmite from Southern Oman. Science 300, 1737-1739.

Fontes, J.C., Gasse, F., Gibert, E., 1996. Holocene environmental changes in Lake Bangong basin (Western Tibet). Part 1: chronology and stable isotopes of carbonates of a Holocene lacustrine core. Palaeogeogr. Palaeoclimatol. Palaeoecol. 120, 25-47.

Gasse, F., Arnold, M., Fontes, J.C., Fort, M., Gibert, E., Huc, A., Li, B., Li, Y., Liu, Q., Melieres, F., Van Campo, E., Wang, F., Zhang, Q., 1991. A 13,000-year climate record from western Tibet. Nature 353, 742-745.

Gupta, A.K., Anderson, D.M., Overpeck, J.T., 2003. Abrupt changes in the Asian southwest monsoon during the Holocene and their links to the North Atlantic Ocean. Nature 421, 354-356.

Gupta, A.K., Das, M., Anderson, D.M., 2005. Solar influence on the Indian summer monsoon during the Holocene. Geophys. Res. Lett. 32, L17703.

Haigh, J., 1996. The impact of solar variability on climate. Science 272, 981-984.

Herzschuh, U., 2006. Palaeo-moisture evolution in monsoonal Central Asia during the last 50,000 years. Quat. Sci. Rev. 25, 163-179.

Herzschuh, U., Winter, K., Wünnemann, B., Li, S.J., 2006. A general cooling trend on the central Tibetan Plateau throughout the Holocene recorded by the Lake Zigetang pollen spectra. Quat. Int. 154-155, 113-121.

Hodell, D.A., Schelske, C.L., 1998. Production, sedimentation, and isotopic composition of organic matter in Lake Ontario. Limnol. Oceanogr. 43, 200-214.

Hollander, D.J., McKenzie, J.A., 1991. $\mathrm{CO}_{2}$ control on the carbon-isotope fractionation during aqueous photosynthesis: a paleo- $\mathrm{\rho CO}_{2}$ barometer. Geology 19, 929-932.

Jin, Z.D., Wu, Y.H., Zhang, X.H., Wang, S.M., 2005. Role of late glacial to mid-Holocene climate in catchment weathering in the central Tibetan Plateau. Quat. Res. 63,161-170.

Keigwin, L.D., 1996. The Little Ice Age and Medieval Warm Period in the Sargasso Sea. Science 274, 1504-1508.

Krishnamurthy, R.A., Bhattacharya, S.K., Kusumgar, S., 1986. Palaeoclimatic changes deduced from ${ }^{13} \mathrm{C} /{ }^{12} \mathrm{C}$ and $\mathrm{C} / \mathrm{N}$ ratios of Karewa lake sediments, India. Nature 323, 150-152.

Li, C., Yanai, M., 1996. The onset and interannual variability of the Asian summer monsoon in relation to land-sea-contrast. J. Climate 9, 358-375.

Liu, X.Q., Dong, H.L., Rech, J.A., Matsumoto, R., Yang, B., Wang, Y.B., 2008. Evolution of Chaka Salt Lake in NW China in response to climatic change during the Latest Pleistocene-Holocene. Quat. Sci. Rev. 27, 867-879.

Meyers, P.A., 2001. Sediment organic matter. In: Last, W.M., Smol, J.P. (Eds.), Tracking Environmental Change Using Lake Sediments. Physical and Geochemical Methods, vol. 2. Kluwer academic publishers, London, pp. 239-269.

Morrill, C., Overpeck, J.T., Cole, J.E., Liu, K., Shen, C., Tang, L., 2006. Holocene variations in the Asian monsoon inferred from the geochemistry of lake sediments in central Tibet. Quat. Res. 65, 232-243.

Neff, U., Burns, S.J., Mangini, A., Mudelsee, M., Fleitmann, D., Matter, A., 2001. Strong coherence between solar variability and the monsoon in Oman between 9 and 6 kyr ago. Nature 411, 290-293.

Norris, R.S., Burrows, A.S., Fieldhouse, R.W., 1994. British, French and Chinese Nuclear Weapons. Westview Press, Boulder, pp. 333-336.

O'Leary, M.H., 1988. Carbon isotopes in photosynthesis. BioScience 38, 328-336.

Oldfield, F., Appleby, P.G., 1984. Empirical testing of ${ }^{210} \mathrm{~Pb}$-dating models for lake sediments. In: Haworth, E.Y., Lund, J.W.G. (Eds.), Lake Sediments and Environmental History. Leicester University Press, Leicester, pp. 93-124.

Overpeck, J., Anderson, D., Trumbore, S., Prell, W., 1996. The southwest Indian Monsoon over the last 18,000 years. Clim. Dyn. 12, 213-225.

Reimer, P.J., Baillie, M.G.L., Bard, E., Bayliss, A., Beck, J.W., Bertrand, C.J.H., Blackwell, P.G., Buck, C.E., Burr, G.S., Cutler, K.B., Damon, P.E., Edwards, R.L., Fairbanks, R.G., Friedrich, M., Guilderson, T.P., Hogg, A.G., Hughenk, K.A., Kromer, B., McCormac, F.G., Manning, S.W., Ramsey, C.B., Reimer, R.W., Remmele, S., Southon, J.R., Stuiver, M., Talamo, S., Taylor, F.W., van der Plicht, J., Weyhenmeyer, C.E., 2004. IntCal04 terrestrial radiocarbon age calibration, 0-26 Cal kyr BP. Radiocarbon 46, 1029-1058.

Rind, D., 2002. The Sun's role in climate variations. Science 296, 673-677.

Rind, D.J., Overpeck, J.T., 1993. Arctic environmental change of the last four centuries. Quat. Sci. Rev. 12, 357-374.

Robbins, J.A., 1978. Geochemical and geophysical applications of radioactive lead. In: Nriagu, J.O. (Ed.), The Biogeochemistry of Lead in the Environment. Elsevier/NorthHolland Biomedical Press, New York, pp. 285-393.

Ruddiman, W., Kutzbach, J., 1991. Plateau uplift and climatic change. Sci. Am. 264, $66-75$. 
Schulz, M., Mudelsse, M., 2002. REDEFIT: estimation red-noise spectra directly from unevenly spaced paleoclimatic time series. Comput. Geosci. 28, 421-426.

Selvaraj, K., Chen, C.T.A., Lou, J.Y., 2007. Holocene East Asian monsoon variability: links to solar and tropical Pacific forcing. Geophys. Res. Lett. 34, L01703.

Shao, X.M., Huang, L., Liu, H.B., Liang, E.Y., Fang, X.Q., Wang, L.L., 2005. Reconstruction of precipitation variation from tree rings in recent 1000 years in Delingha, Qinghai. Sci. China, Ser. D 48, 939-949.

Shen, J., Liu, X.Q., Wang, S.M., Matsumoto, R., 2005. Paleoclimatic changes in the Qinghai Lake area during the last 18,000 years. Quat. Int. 136, 131-140.

Shindell, D.T., Schmidt, G.A., Mann, M.E., Rind, D., Waple, A., 2001. Solar forcing of regional climate change during the Maunder Minimum. Science 294, 2149-2152.

Smith, B.N., Epstein, S., 1971. Two categories of ${ }^{13} \mathrm{C} /{ }^{12} \mathrm{C}$ ratios for plants. Plant Physiol. 47, 380-384.

Stuiver, M., 1975. Climate versus changes in ${ }^{13} \mathrm{C}$ content of the organic component of lake sediments during the Late Quarternary. Quat. Res. 5, 251-262.

Stuiver, M., Braziunas, T.F., 1993. Sun, ocean climate and atmospheric ${ }^{14} \mathrm{CO}_{2}$ : an evaluation of causal and spectral relationships. Holocene 3, 289-304.

Stuiver, M., Reimer, P.J., Bard, E., Beck, J.W., Burr, G.S., Hughen, K.A., Kromer, B., McCormac, G., van der Plicht, J., Spurk, M., 1998. INTCAL98 radiocarbon age calibration, 24,000-0 cal BP. Radiocarbon 40, 1041-1083.

Thompson, L.G., Mosley-Thompson, E., Davis, M.E., Bolzan, J.F., Dai, J., Yao, T., Gundestrup, N., Wu, X., Klein, L., Xie, Z., 1989. Holocene-Late Pleistocene climatic ice core records from Qinghai-Tibetan Plateau. Science 246, 474-477.

Versteegh, G.J.M., 2005. Solar forcing of climate. 2: evidence from the past. Space Sci. Rev. 120, 243-286.

Wang, B., 2006. The Asian Monsoon. Springer/Praxis Publishing, New York.
Wang, P.X., Clemens, S., Beaufort, L., Braconnot, P., Ganssen, G., Jian, Z.M., Kershaw, P. Sarnthein, M., 2005a. Evolution and variability of the Asian monsoon system: state of the art and outstanding issues. Quat. Sci. Rev. 24, 595-629.

Wang, Y.J., Cheng, H., Edwards, R.L., He, Y., Kong, X., An, Z.S., Wu, J., Kelly, M.J., Dykoski, C.A Li, X., 2005b. The Holocene Asian Monsoon: links to solar changes and North Atlantic climate. Science 308, 854-857.

Webster, P.J., 1987. The elementary monsoon. In: Fein, J.S., Stephens, P.L. (Eds.) Monsoons. John Wiley, New York, pp. 3-32.

Weltje, G., 1997. End-member modelling of compositional data: Numerical-statistical algorithms for solving the explicit mixing problem. J. Math. Geol. 29, 503-549.

Weltje, G.J., Prins, M.A., 2003. Muddled or mixed? Inferring palaeoclimate from size distributions of deep-sea clastics. Sediment. Geol. 162, 39-62.

Weltje, G.J., Prins, M.A., 2007. Genetically meaningful decomposition of grain-size distributions. Sediment. Geol. 202, 409-424.

Xiao, S., Chen, F.H., Oiang M.R. Zhang, J.W., Zhou, A.F., Sun, D.H., 2007. Distribution pattern of grainsize in surface sediments from Sugan Lake and its potential in recording aeolian dust in arid China. Acta Geogr. Sin. 62, 1153-1164 (in Chinese with English abstract).

Ueda, H., Kamahori, H., Yamazaki, N., 2003. Seasonal contrasting features of heat and moisture budgets between the eastern and western Tibetan Plateau during the GAME IOP. J. Climate 16, 2309-2324.

Zhang, P.Z., Cheng, H., Edwards, R.L., Chen, F.H., Wang, Y.J., Yang, X.L., Liu, J., Tan, M., Wang, X.F., Liu, J.H., An, C.L., Dai, Z.B., Zhou, J., Zhang, D.Z., Jia, J.H., Jin, L.Y., Johnson, K.R., 2008. A test of climate, sun, and culture relationships from an 1810-year Chinese cave record. Science 322, 940-942. 